\title{
India-Gulf Trade Relations
}

\author{
Dr. Prasann Kumar Das, \\ Asst. Professor Economics, IPSAR, Cuttack, Odisha, India
}

\author{
Dr.SamirRanjanPradhan, \\ Senior Economist, Doha, Qatar
}

\begin{abstract}
This paper analyses India's trade relations with the Gulf region comprising six members of the Gulf Cooperation Council (GCC) -- namely, Bahrain, Kuwait, Oman, Qatar, Saudi Arabia and the United Arab Emirates (UAE) - Iran and Iraq. While it is evident that India's trading relations with the Gulf region has transformed considerably over the years primarily underpinned by burgeoning economic growth, the structure and pattern of trade is yet to be diversified. The bilateral trade volume has surpassed USD100 billion mark, but, India's export basket continues to be concentrated to few traditional items, signifying less dynamism. Notably, the higher growth in bilateral trade has happened in the absence of any specialised policy framework for trade promotion, although there are occasional bilateral interactions and exchanges involving multiple stakeholders. There are huge potentials for diversifying India's export structure based on certain new growth sectors in which India has global comparative advantages with respect to the Gulf regions' imports structure. Therefore, there is a pervasive need for a unified Gulf specific trade strategyinvolving government, private sector and trade bodies, which could be called, GULF DIRECT. Such a special strategy would not only diversify India's trade basket, but, would also synergise other economic and commercial avenues of cooperation with the strategically important Gulf region.
\end{abstract}

Key Words: Gulf Region, Gulf Direct Global economy, Global Hub, Trade Intensity Index, Energy Economy, Bilateral Trade,

\section{Introduction}

As the second decade of the 21st century unfolds, the global economy is poised at a critical juncture. As the world exits from the 2008-09 financial crisis, the growing clout of emerging markets is paving the way for a world economy with an increasingly multipolar character. Going forward, the distribution of global growth will become more diffuse, with no single country dominating the global economic scene.

The seeds of this change were planted some time ago. Over the past two decades, the world has witnessed emerging economies rise to become a powerful force in international production, trade, and finance. Emerging and developing countries' share of international trade flows has risen steadily, from 26 percent in 1995 to an estimated 42 percent in 2010 (World Bank, 2011). Much of this rise has been due to an expansion of trade not between developed countries and developing countries, but among developing countries. Similarly, more than one-third of foreign direct investment in developing countries currently originates in other developing countries. Emerging economies have also increased their financial holdings and wealth. Emerging and developing countries now hold three-quarters of all official foreign exchange reserves (a reversal in the pattern of the previous decade, when advanced economies held two-thirds of all reserves), and sovereign wealth funds and other pools of capital in developing countries have become key sources of international investment. At the same time, the risk of investing in emerging economies has declined dramatically. The growing trade and economic relations between India and the Gulf region over the last decade vividly manifest such global transformation in which the two regions have emerged as a critical economic mass in the global economy.

The economic and financial crisis that shook the world economy in the closing months of 2008 produced a global recession in 2009 that resulted in the largest decline in world trade in more than 70 years. The rate of trade growth had already slowed from 6.4 per cent in 2007 to 2.1 per cent in 2008, but the 12.2 per cent contraction in 2009 was without precedent in recent history (WTO, 2010). However, bilateral trade between India and the Gulf region which declined in the crisis year 2009, swiftly recovered to higher growth trajectory at USD 105 billion in 2010 .

Against this background, the objectives of this paper are to: (i) review trade relations between India and the Gulf region (ii) provide quantitative measures of trade integration between the two and (iii) highlight policy catalysts for trade promotion. The paper is organized in four parts: the second part reviews recent macroeconomic trends in the Gulf region and India, the third part analyses bilateral trade trends and potentials between India and the Gulf region, and the fourth part discusses the next steps in promoting bilateral trade relationships. 


\section{Macroeconomic Context And Trade Performance}

Over the last decade, India's growth miracle has created ripple effects in the world economy and in particular in its economic relations with its extended neighbourhood, i.e., the Gulf region. Simultaneously, the Gulf's (GCC in particular) relentless economic growth backed by higher oil revenues have also created substantial opportunities for deepening cooperation with emerging Asian giants such as India. The convergence of synergies primarily eked out from the energy-economy matrix proclaims the dawn of a promising era in the annals of India-Gulf cooperation, bearing multidimensional connotations for the contemporary discourse on global political economy, primarily centering on incipient 'open regionalism' and 'gradual multilateralism'. The most important strands of such evolving regional interdependence can be gleaned from the current as well as future trends of regional and bilateral merchandise trade. Figure 1 depicts the real GDP growth rates of India and the Gulf countries for the period 2000-2011.

The Indian economy exhibited broad based recovery in the second half of 2009-10 from the slowdown that had started in the second half of 2008-09. Real GDP growth showed a turnaround from 6.7 per cent in 2008-09 to 7.4 per cent in 2009-10. In relation to the pre-global crisis high growth phase of 8.9 per cent recorded during 2003-08, however, it suggests the scope for further acceleration.

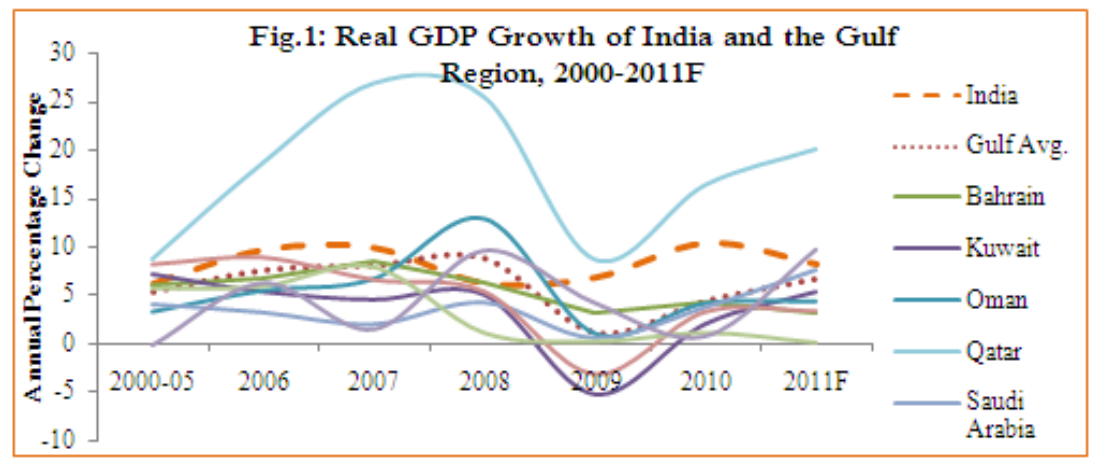

Note: F means forecast. Source: Author based on IMF World Economic Outlook Database, April 2011.

A strong recovery in industrial sector combined with a resilient services sector muted the impact of a deficient South-West monsoon on overall output. The contribution of the industrial sector to the overall growth increased sharply from 9.5 per cent in 2008-09 to 28 per cent in 2009-101.

A recent study examining the impact of the global crisis shows that there was no or negligible potential growth reductions in the case of China, Indonesia, and India. In the case of India, it is due to its lower level of export dependency compared to the East Asian economies. Estimates suggest a drop in potential output growth in most of the emerging East Asian economies, albeit, marginally in the case of India (i.e., by 0.4 percentage points) (Park C.Y. et al, 2010). However, India's growth trajectory is mostly domestic demand driven and even in the absence of the global crisis, India might have still experienced some moderation due to cyclical factors. The cyclical factors revert to their underlying trend in due course of time, as the GDP series in India essentially follows a trend stationary process. In fact during Q4: 2009-10, fixed capital formation growth exhibited significant acceleration. With fiscal consolidation, favorable demography, and further structural reforms, the potential growth path could be raised to double-digit level.

Similarly, the resilience of the Gulf countries especially the GCC economies during the steep global recession and slump in oil prices is testament in part to the successful economic diversification and development programs which have been pursued over the past couple of decades. While still heavily dependent on hydrocarbon revenues, GCC economies are undergoing an impressive economic transformation which has resulted in growing non-oil sectors. In addition, governments have taken advantage of the boom in oil revenues during 2003-08 to build up large external savings. These external assets have been drawn upon to smooth the downturn in revenues following the steep decline in oil prices from their mid- 2008 highs, helping to sustain growth in the region's non-oil sectors despite the difficulties presented by the slump in global trade and growth. In most GCC countries expanding non-oil sectors during 2009 were sufficient to keep overall real GDP growth positive, despite large contractions in oil sectors as both production (due to cuts in OPEC quotas) and prices fell. The ability of the GCC to use counter cyclical fiscal policy to support their economies stems from its dual approach to utilizing its oil wealth. Consistent with the oft cited 'permanent income hypothesis ${ }^{2}$, GCC

1 Reserve Bank of India (RBI), Annual Report 2010.

2 This seeks constant government consumption (in real terms) of oil resources over time that is equivalent to interest income on the net present value of a country's oil wealth, and entails the use of a permanent fund for 
governments have saved a large proportion of oil revenues which have been invested into foreign assets (often through Sovereign Wealth Funds), the returns from which support spending on the non-oil budget. At the same time, GCC governments have used oil and gas revenues to fuel industrial development, and large scale public infrastructure and investment programs, including in education, aimed at improving the environment and returns for private investment, and boosting employment outside the government sector. Where completed, these investment programs have already helped expand productive capacity outside the immediate oil sector (for example in petrochemicals, aluminum, tourism and trade), and during implementation have fuelled strong growth in GCC construction sectors.

The economic growth of the other two Gulf economies, namely Iran and Iraq has been seriously affected due to political conflicts and global economic sanctions. As a result, the outlook for them seems to be highly uncertain. Nevertheless, being large oil producers, they will continue their global interaction, especially in case of Iraq, it is quite visible in the last few years.

With growth buoyancy, substantial changes have been witnessed in the trade profile of India and the Gulf countries over the years. India's liberalisation process has been accompanied by a more stable and transparent trade policy regime, with a medium to long-term view of policy as opposed to a short-run annual approach with unpredictable and discreet changes therein. Hence, the new Foreign Trade Policy (FTP) 2004-09 (which subsumes the 2002-07 Trade Policy) takes an integrated view of the overall development of India's foreign trade and is built around two major objectives. First, that of doubling India's share of global merchandise trade by 2009 and secondly, the use of trade policy as an effective instrument of economic growth with a strong emphasis on employment generation (FTP, 2009-2010). With regard to specifics the policy aims at unshackling controls and creating an atmosphere of trust and transparency by bringing down transactions costs and identifying and nurturing focus areas to develop India as a global hub for manufacturing, trade and services. This is to be achieved in various ways which include: the role of state governments in providing an enabling environment for boosting international trade by setting up an Inter-State Trade Council; the revitalization of the Board of Trade by redefining its role and through the involvement of experts on trade policy; avoiding an inverted duty structure and ensuring that domestic sectors are not disadvantaged in trade agreements through wider stakeholders consultations; and through the encouragement of the greater integration of the Indian economy into the world economy both via the multilateral process, but also increasingly through regional trading arrangement. Such positive policy changes have resulted in India's world trade performance in the recent past ${ }^{3}$.

\begin{tabular}{|c|c|c|}
\hline \multicolumn{3}{|c|}{ Box 1 : Summary of India's Trade Agreements at a Glance } \\
\hline Existing & Ongoing & $\begin{array}{l}\text { FTAs /PTAs under Study } \\
\text { and Consideration }\end{array}$ \\
\hline $\begin{array}{l}\text { Bankok Agreement; Global System of Trade } \\
\text { Preferences (GSTP); SAARC Preferential Trading } \\
\text { Agreement SAPTA); } \\
\text { India-Sri Lanka FTA; India - Thailand FTA; India } \\
\text { Singapore Comprehensive Economic Cooperation } \\
\text { (CECA); Indo-Nepal Trade Treaty; India- } \\
\text { Mauritius PTA; India-Chile PTA }\end{array}$ & $\begin{array}{l}\text { Indo-ASEAN CECA; India-Malaysia } \\
\text { FTA; South Asian Free Trade } \\
\text { Agreement (SAFTA); BIMSTEC (Bay } \\
\text { of Bengal Initiative for Multi-Sectoral } \\
\text { Technical \& Economic Cooperation); } \\
\text { India - MERCOSUR PTA }\end{array}$ & $\begin{array}{l}\text { Gulf Cooperation Council } \\
\text { (GCC); China; South Korea; } \\
\text { Japan; Pakistan; Southern } \\
\text { African Customs Union } \\
\text { (SACU); Egypt; Israel; } \\
\text { Russia; Australia ; New } \\
\text { Zealand }\end{array}$ \\
\hline
\end{tabular}

Source: WTO RTA Database, 2011

By virtue of being exhaustible resource-based, rent-seeking economies and consequent low absorption capacities reflecting low production base; trade and related activities constitute the cornerstone of the Gulf countries' economic activities. While, earlier, exports (petroleum) were prominent in Gulf countries' global trade profile in comparison to imports; with the albeit diversification of economic base primarily by optimizing the oil value chain and other sectors like financial and tourism, imports started to leapfrog in the global trade portfolio, thereby signifying the domestic economic dynamism. Currently this dynamism is gaining strength day by day, implying the epic quest for diversification of their narrow economic base.

Over the boom period, 2005-2008, India and Gulf economies have performed very well in world trade. India's higher growth has precipitated sharp increase in imports, while exports have also registered impressive growth. During that period, India's exports and imports have registered compound average growth rates (CAGR) of 23.8 percent and 31 percent respectively. However, India's share in world trade continues to be low at only 2 percent (See Table 1).

future generations to secure intergenerational equity and guarantee a permanent flow of resources that will foster economic development even after oil resources have been exhausted. 3Department of Commerce, Government of India. 
Table 1: India and the Gulf Economies in World Trade (USD Billion)

\begin{tabular}{|c|c|c|c|c|c|c|c|}
\hline & & 2005 & 2006 & 2007 & 2008 & 2009 & 2010 \\
\hline \multirow{5}{*}{ India } & Export & 100 & 122 & 150 & 195 & 165 & 217 \\
\hline & Import & 143 & 178 & 229 & 321 & 257 & 324 \\
\hline & Total Trade & 243 & 300 & 379 & 516 & 422 & 541 \\
\hline & Trade Balance & -43 & -56 & -79 & -126 & -92 & -107 \\
\hline & & 2005 & 2006 & 2007 & 2008 & 2009 & 2010 \\
\hline \multirow{4}{*}{ Gulf } & Export & 454 & 552.6 & 594.4 & 859.9 & 670 & 797 \\
\hline & Import & 226.8 & 262.02 & 327.3 & 419.5 & 348 & 376 \\
\hline & Total Trade & 680.8 & 814.62 & 921.7 & $1,279.4$ & 1,018 & 1,173 \\
\hline & Trade Balance & 227.2 & 290.58 & 267.1 & 440.4 & 322 & 421 \\
\hline \multirow{6}{*}{ World } & & 2005 & 2006 & 2007 & 2008 & 2009 & 2010 \\
\hline & Export & 10,338 & 11,952 & 13,776 & 15,945 & 12,349 & 14,879 \\
\hline & Import & 10,578 & 12,183 & 14,012 & 16,184 & 12,453 & 15,020 \\
\hline & Total Trade & 20,916 & 24,135 & 27,788 & 32,129 & 24,802 & 29,899 \\
\hline & Trade Balance & -240 & -231 & -236 & -239 & -104 & -141 \\
\hline & & 2005 & 2006 & 2007 & 2008 & 2009 & 2010 \\
\hline \multirow{3}{*}{$\begin{array}{l}\text { India's } \\
\text { share }\end{array}$} & Export & $1 \%$ & $1 \%$ & $1 \%$ & $1 \%$ & $1 \%$ & $1 \%$ \\
\hline & Import & $1 \%$ & $1 \%$ & $2 \%$ & $2 \%$ & $2 \%$ & $2 \%$ \\
\hline & Total Trade & $1 \%$ & $1 \%$ & $1 \%$ & $2 \%$ & $2 \%$ & $2 \%$ \\
\hline \multirow{3}{*}{$\begin{array}{l}\text { Gulf's } \\
\text { share }\end{array}$} & Export & $4 \%$ & $5 \%$ & $4 \%$ & $5 \%$ & $5 \%$ & $5 \%$ \\
\hline & Import & $2 \%$ & $2 \%$ & $2 \%$ & $3 \%$ & $3 \%$ & $3 \%$ \\
\hline & Total Trade & $3 \%$ & $3 \%$ & $3 \%$ & $4 \%$ & $4 \%$ & $4 \%$ \\
\hline
\end{tabular}

Source: Author's calculation based on International Trade Centre (ITC) Trade Database, 2011.

The Gulf economies have also performed very well in world trade over the period 2005-2008. Gulf economies' export and import registered a CAGR of 22.3 and 21.4 percent respectively during the period 2005 2008. Notably Gulf's share in world trade is 4 percent (See table 1). Both India and Gulf witnessed deceleration in exports and imports in trade during the crisis year 2009, however, recovery in 2010 was swift.

\section{India's Tarde With The Gulf Region: Trends And Patterns}

India's trade with the Gulf region has a history dating back to the Silk Road days. While trade along the Silk Road sank into oblivion due to the downfall of the Roman Empire, trade between India and the Gulf remained brisk to an extent that the Indian Rupee was widely circulated as currency in the Gulf countries from medieval times onwards. Especially in the early and mid 20th century, the Indian Rupee was widely adopted as legal tender in the Gulf countries and even adopted as local currency in the form of the Gulf Rupee between 1959 and 1966.

Enhancing trade cooperation requires a proper understanding of the level and trends in bilateral trade. It is also essential to assess the relative importance of the Gulf countries as important trading partners and their significance in India's global trade. An important aspect in this context is to examine the fluctuations in the volume and composition of bilateral trade flows over a period of time. An analysis of trade composition and understanding of the nature of trade facilitation measures, comparative advantages, and potential for trade expansion are also necessary for devising a trade-augmenting bilateral policy framework.

Over the last decade, trade relations between the two regions have developed by leaps and bounds. In 2010, the West Asia and North Africa (WANA) region ${ }^{4}$ accounted for the largest share in India's world trade. Importantly the Gulf region's share in India's world trade was 22 percent, making it the single largest trading partner (See Figure 2).

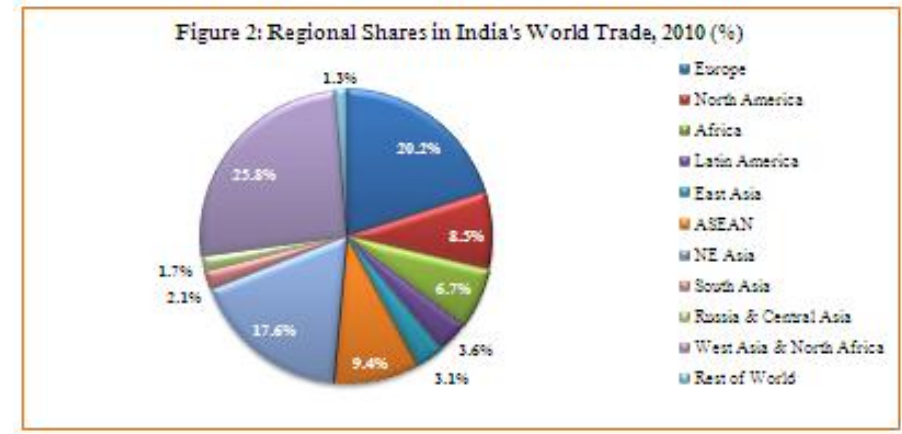

Source: Author's calculation based on Ministry of Commerce Database, May 2011.

4 As per the Ministry of Commerce database, WANA region comprises of countries namely, Bahrain, Kuwait, Oman, Qatar, Saudi Arabia, UAE, Iran, Iraq, Egypt, Syria, Lebanon, and Algeria. 
Notably, WANA region accounted for the largest share in India's total exports and imports from the world in the year 2010 (See Figure 3 and Figure 4). Gulf region's share in India's world trade was 18 percent for exports and 25 percent for imports respectively. Moreover, in the Gulf region, UAE is India's single largest trading partner followed by Saudi Arabia, Iran, Kuwait, Iraq, Qatar, Oman and Bahrain (See figure 5).

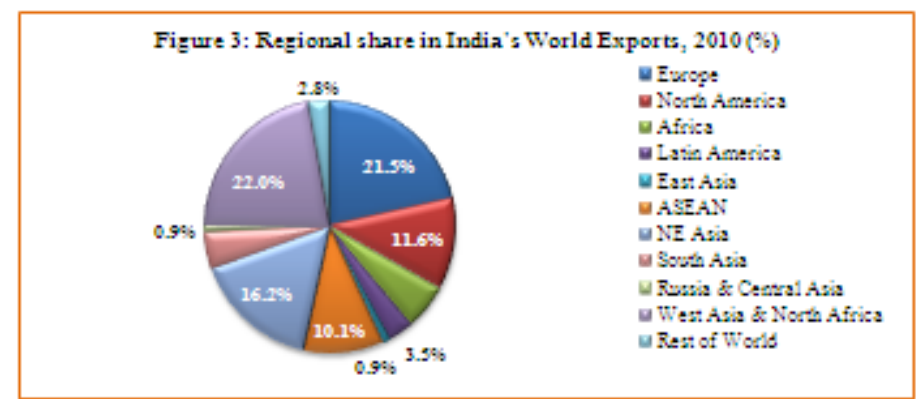

Source: Author's calculation based on Ministry of Commerce Database, May 2011.

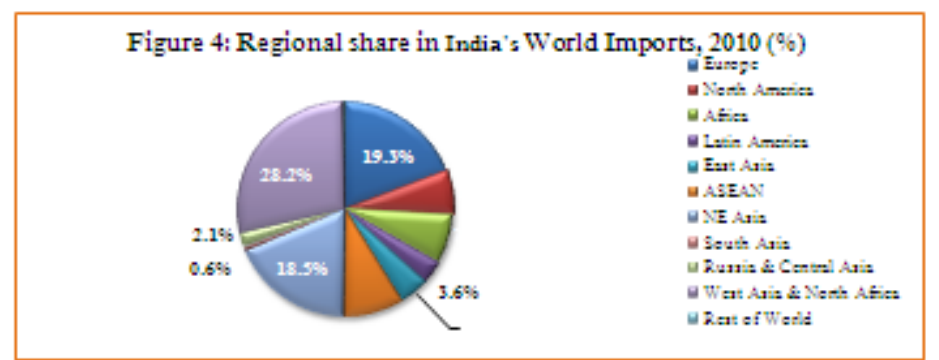

Source: Author's calculation based on Ministry of Commerce Database, May 2011.

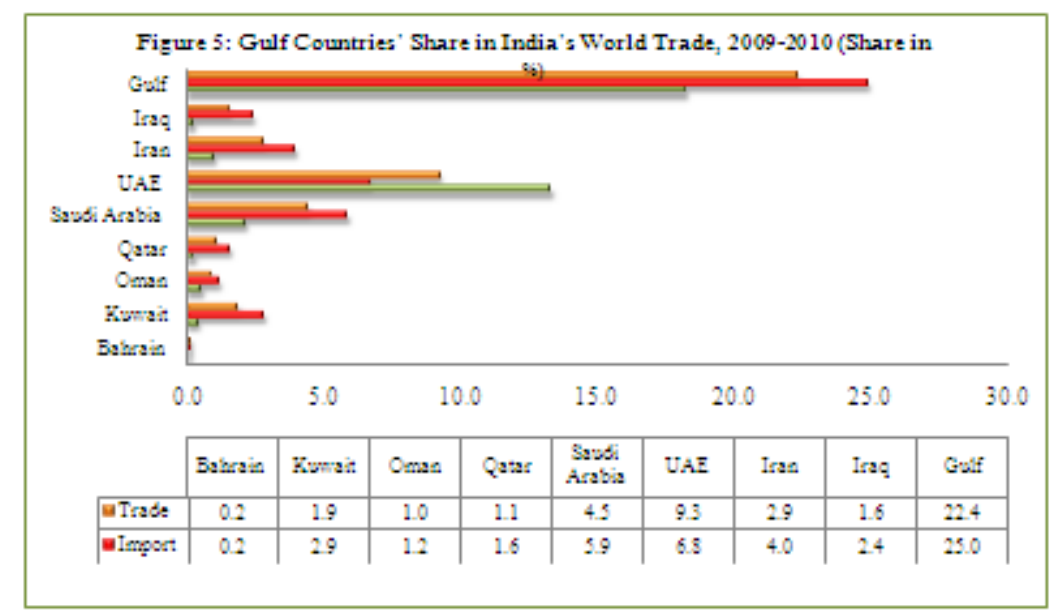

Over the last decade, India's trade with the Gulf region has registered a five-fold increase in volume from USD 6.1 billion in 2000-01 to nearly 115 billion in the year 2008-09. In fact, the compound annual average growth rate (CAGR) of bilateral trade between India and the Gulf region was staggering at 23 percent over the last five years (2004/05 to 2008/09). Due to the global financial crisis, there was a marginal decline in India-Gulf trade, which was 105 billion in the year 2009-2010 (See Figure 6). Over the last decade (2000-2001 to 2008-2009), India's exports to and imports from the Gulf region have registered CAGR of 27 percent and a staggering 51 percent respectively 


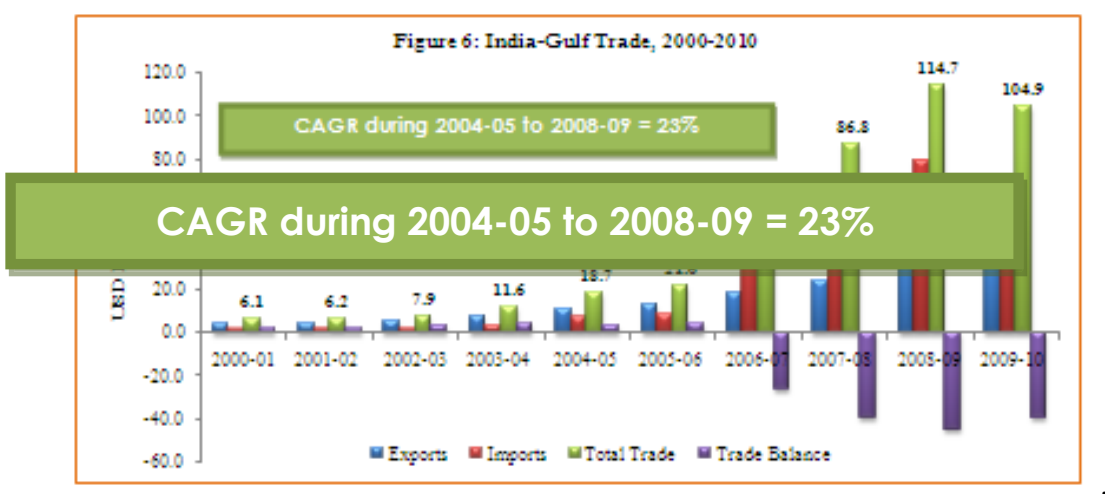

Source: Author's calculation based on Ministry of Commerce Database, May 2011.

Despite the outstanding growth in trade volume, the structure and pattern of India-Gulf trade depicts a very contrasting picture. An analysis of the composition of India's exports to the Gulf region based on comparable data from ITC/UNCTAD/WTO, suggests that five sectors at HS 2-digit sectors account for 65 per cent of exports. These are 72-Iron \& steel, - Mineral fuels, oils, distillation products, etc; 10- Cereals; "85Electrical, electronic equipment; and '74- Copper and articles thereof. The rest is accounted for by a whole range of sectors with medium and low shares.

Similarly, the composition of India's imports from the Gulf region suggest that five sectors at HS 2digit level account for an average share of 75 per cent of imports from the Gulf region over the period 20052009. These products belong to Chapters 27 (mineral fuels etc.), 26- Ores, slag, ash, 71 (pearls, precious stones), 28-Inorganic chemicals, and 29 (organic chemicals).

This implies that India's export basket is not only characterized by high concentration but also thinly spread shares across a wide range of sectors. In other words, the trade profile is not diversified and is also heavily concentrated to limited items.Importantly, higher prices of oil and gas have resulted in negative terms of trade for India. India's import prices from the Gulf region have almost doubled during the period 2000-08, spurred by the rise in prices for fuel commodities, while export prices rose by 20-25 percent. It is also important to note that trade between the two regions is largely based on export-import complementarities, suggesting increasing economic interdependence and convergence in the future.Table 2 and Table 3 depict India's top 20 export and import items to and from the Gulf region in the year 2009-2010.

Table 2: Top-20 Export Items to the Gulf Region, 2009-2010

\begin{tabular}{|c|c|c|c|}
\hline Rank & HS Code & Predoct Name & $\begin{array}{l}\text { Pane (USi) } \\
\text { Mnition) }\end{array}$ \\
\hline 1 & 72 & Iron and stas! & $12,692,41$ \\
\hline 2 & 27 & 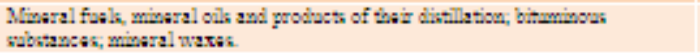 & $5,871,90$ \\
\hline 3 & 10 & Carsale. & 2,05035 \\
\hline 4 & 35 & 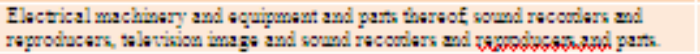 & $1,018.48$ \\
\hline s & 74 & Coppor and artielas thars of & 355.52 \\
\hline 5 & 63 & Othar made up taxtils artilas, sats, worn clothing axd worn taxtila artelas, rags & 79329 \\
\hline 7 & 85 & 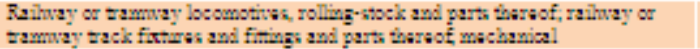 & 557.13 \\
\hline$\$$ & 62 & 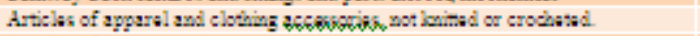 & 500.81 \\
\hline 9 & 73 & Artilas of irom or stas! & 445.81 \\
\hline 10 & 29 & Organis ehomicals & $40 s s s$ \\
\hline 11 & $\$$ & Edibla frut axd muth, pasl or elrou frut or malama. & 369.11 \\
\hline 12 & $\$ s$ & Nax-mado stapla flomes & $365: 52$ \\
\hline 13 & $\$ 4$ & 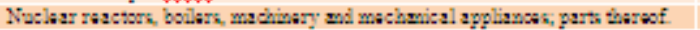 & 34723 \\
\hline 14 & 2 & Mast and adibla mast offal & 318.03 \\
\hline 15 & 25 & 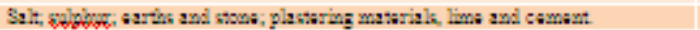 & 315.85 \\
\hline 16 & 9 & Coffos, ta2, mats and spicse. & 29592 \\
\hline 17 & 40 & Rubbar and artelas tharsof. & 25633 \\
\hline 18 & 90 & 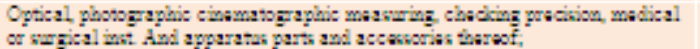 & 271.08 \\
\hline 19 & 73 & Niskal and articlas thare of & 299.13 \\
\hline 20 & 28 & 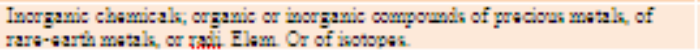 & 257.14 \\
\hline
\end{tabular}

Source: Author's calculation based on Ministry of Commerce Export-Import Database, May 2011. 


\begin{tabular}{|c|c|c|c|}
\hline Rank & HS Code" & Product Name & Value (USD Million) \\
\hline 1 & 27 & $\begin{array}{l}\text { Mineral fuels, mineral oils and products of their distillation; bituminous } \\
\text { substances; mineral waxes. }\end{array}$ & $39,145.89$ \\
\hline 2 & 26 & Ores, sleg and ash. & 15.723 .65 \\
\hline 3 & 71 & $\begin{array}{l}\text { Natural or cultured peurls, precious or semiprecious stonespre methls clact. } \\
\text { with pre metal and ancls thereof,imitjewiry, coin. }\end{array}$ & $11,257.53$ \\
\hline 4 & 28 & $\begin{array}{l}\text { Inorgenic chemicals; orgenic or inorganic compounds of precious metals, of } \\
\text { rere-surh metals, or fadi Elem Or of isotopes. }\end{array}$ & 992.13 \\
\hline 5 & 29 & Organic chemicals & 675.48 \\
\hline 6 & 31 & Fentilisers. & 637.53 \\
\hline 7 & 39 & Plastic and anticles thereof. & 51931 \\
\hline 8 & 38 & Miscellensous chemical products. & 468.09 \\
\hline 9 & 72 & Iron and stesl & 37725 \\
\hline 10 & 76 & Aluminium and anticles thereof. & 320.63 \\
\hline 11 & 85 & $\begin{array}{l}\text { Electrical machinery and equipment and parts thereof, sound recorders and } \\
\text { reproducers, television image and sound recorders and reproducers, and } \\
\text { parts. }\end{array}$ & 236.42 \\
\hline 12 & 74 & Copper and articles thersof. & 229.49 \\
\hline 13 & 25 & Salt; sulphur, earths and stone; plasteringmaterials, lime and cement. & 190.28 \\
\hline 14 & 89 & Ships, bouts and flozting structures. & 11536 \\
\hline 15 & 84 & $\begin{array}{l}\text { Nuclear reactors, boilers, machinery and mechanical appliances; parts } \\
\text { thereof. }\end{array}$ & 103.47 \\
\hline 16 & 70 & Glass and glassware. & 92.68 \\
\hline 17 & 8 & Edible fruit and nuts, peel or citus frut or melons. & 88.73 \\
\hline 18 & 30 & Phamaceutical products & 7694 \\
\hline 19 & 49 & $\begin{array}{l}\text { Printed books, newspapers, pictures and other products of the printing } \\
\text { industry; manuscripts, typescripts and plans. }\end{array}$ & 6790 \\
\hline 20 & 65 & Headgear and parts thereof & 6096 \\
\hline
\end{tabular}

Source: Author's calculation based on Ministry of Commerce Export-Import Database, May 2011.

\section{Trade Intensity Index Between India And The Gulf Region}

Previous section depicted India's exports composition to the Gulf region. Nevertheless, it says little about India's strong export and commodity sectors. In the light of an increasingly competitive international environment, it is useful to examine where India's comparative advantage lies with respect to the Gulf regional market. It is evident from Table 4 that India's export intensity as well as import intensity with the Gulf region is above one for most of the years (especially after the year 1998). This means India's exports and imports are intense with the Gulf countries compared with its trading pattern with rest of the world. The natural trading partner theory reveals countries tend to trade more with neighbors and close proximate partners. The Gulf countries being geographically closer to India, value of these indices are likely to come down once it is adjusted for geographical distance. India's Import Intensity Index (III) is higher than Export Intensity Index (EII) as it imports more from the Gulf compared to its exports.

Table 4: Trade Intensity Index between India and the Gulf countries

\begin{tabular}{|c|c|c|c|c|}
\hline Year & $\begin{array}{l}\text { India's EII with } \\
\text { Gulf Region }\end{array}$ & $\begin{array}{l}\text { India's III with the Gulf } \\
\text { Region }\end{array}$ & Gulf Region's EII with India & $\begin{array}{l}\text { Gulf Regions' III with } \\
\text { India }\end{array}$ \\
\hline 1990 & 0.42 & 0.72 & 0.87 & 0.32 \\
\hline 1995 & 0.91 & 0.95 & 0.91 & 0.41 \\
\hline 2000 & 1.02 & 1.04 & 1.02 & 0.93 \\
\hline 2005 & 1.09 & 1.13 & 1.27 & 1.04 \\
\hline 2006 & 1.12 & 1.19 & 1.68 & 1.18 \\
\hline 2007 & 1.43 & 1.72 & 1.73 & 1.53 \\
\hline 2008 & 1.64 & 1.86 & 1.90 & 1.61 \\
\hline
\end{tabular}

Source: Author's calculations based on IMF DOTS Database, 2010.

At the disaggregated country-wise level, India's export intensity ${ }^{6}$ is above one for UAE, Saudi Arabia, Iran, Kuwait, Oman. For other Gulf countries (Bahrain, Qatar and Iraq), the export intensity is fluctuating over the years. Moreover, India is importing smaller volumes from countries such as Bahrain, Qatar and Iraq which is reflected in the low Import intensity Index (See Table 5).

5 Estimation techniques for export intensity index and import intensity index is explained in detail in the methodology appendix.

6 The average amount of this index is equal to one, if an index value is greater than one, which means there is a higher degree of trade intensity between two given countries. Opposite of that where the result of the computation is closer to zero, which means there is a lower trade relation. 
Table 5: India's Export and Import Intensity Index with the Gulf countries

\begin{tabular}{|c|c|l|l|l|l|l|l|l|}
\hline Year & & BAH & KUW & OMN & QTR & KSA & UAE & IRN \\
\hline \multirow{2}{*}{1990} & EII & 0.02 & 0.04 & 0.05 & 0.01 & 0.08 & 0.09 & 0.16 \\
\cline { 2 - 9 } & III & 0.12 & 0.29 & 0.27 & 0.13 & 0.63 & 0.57 & 0.97 \\
\hline \multirow{2}{*}{1995} & EII & 0.68 & 0.32 & 0.24 & 0.18 & 0.99 & 1.01 & 0.86 \\
\cline { 2 - 9 } & III & 0.68 & 0.76 & 0.36 & 0.37 & 1.34 & 1.58 & 1.01 \\
\hline \multirow{2}{*}{2000} & EII & 0.93 & 1.02 & 0.98 & 0.98 & 1.26 & 1.34 & 1.02 \\
\cline { 2 - 9 } & III & 0.98 & 1.43 & 0.99 & 0.45 & 1.99 & 1.76 & 1.21 \\
\hline \multirow{2}{*}{2005} & EII & 1.08 & 1.16 & 1.03 & 0.98 & 1.49 & 1.98 & 1.09 \\
\hline \multirow{2}{*}{2006} & III & 1.01 & 1.89 & 1.46 & 1.01 & 2.09 & 1.86 & 1.35 \\
\hline \multirow{2}{*}{2007} & EII & 1.13 & 1.24 & 1.19 & 1.04 & 1.67 & 2.01 & 1.18 \\
\hline & III & 0.92 & 1.91 & 1.67 & 1.54 & 2.17 & 2.35 & 1.86 \\
\hline \multirow{2}{*}{2008} & EII & 1.42 & 1.65 & 1.52 & 1.28 & 2.01 & 2.68 & 1.34 \\
\hline & III & 1.03 & 2.01 & 1.98 & 1.97 & 2.96 & 2.98 & 2.01 \\
\hline & EII & 1.68 & 1.76 & 1.79 & 1.58 & 2.34 & 2.76 & 1.99 \\
\hline
\end{tabular}

Source: Author's calculations based on IMF DOTS Database, 2010.

\section{India's Revealed Comparative Advantage (Rca)}

As the name suggests, revealed comparative advantage indices are intended to reveal which industries a country has a comparative advantage in producing goods from. The revealed comparative advantage index developed by Balassa (Balassa, 1967) assumes that a country's comparative advantage is revealed by its exports to the world. The static revealed comparative advantage of exports is represented by a country's commodity composition of exports vis-à-vis that of the world.

Comparative advantage depends on pre-trade relative prices. Principal determinants of these unobservable relative prices are resource and factor endowments, stages of industrialization (that is level of technology), and demand (Ariff, Mohamed and Tan EuChye, 1992). Difference in these determinants across countries lead to differences in autarky relative prices across countries. When countries trade, they export the goods in which they have comparative advantage and import those in which they have comparative disadvantage. Therefore the structure of trade should reflect a country's pattern of comparative advantage. However, it is possible that actual trade patterns, on which RCA calculations are based, may not reflect true comparative advantage/disadvantage. The divergence between RCA and true comparative advantage results primarily from market distortions caused by government intervention.

As evident from Table 6, India possesses a moderate revealed comparative advantage in several SITC categories at a 1-digit aggregate level. In fact India has possessed an advantage in all categories except for SITC 7 (Machines, transport equip.) over the period 2000 and 2008. It should be noted however that none of the RCA indices greater than 1 calculated for India at the 1-digit aggregation exceed 3, indicating only a relatively weak comparative advantage, which is to be expected given India's large and diverse economy. In 2008, India had a revealed comparative advantage in all aggregated categories except for 7 (Machines, transport equip.), and 4 (Animal, veg. oils, fats, wax).

Further, within $0 \& 1$, an example of an important commodity for India is rice (042). India possesses a strong revealed comparative advantage in this commodity, with values in 2005 and 2008 of over 14 . India also possesses a strong revealed comparative advantage in iron ore, concentrates (281), with values in 2005 and 2008 of 9.33 and 6.65 respectively. SITC $6 \& 8$ (Manufactured goods; Misc. manufactured articles) is another important aggregation of goods for India. India posses a revealed comparative advantage in many industries within this commodity grouping, with strong RCA values. Gold, silverware, jewlnes. (897) is a good example, with static RCA values for 2005 and 2008 exceeding 10. Textile yarn (651), and textile articles nes. (658) also show relatively strong levels of revealed comparative advantage, with index values of above 5.8. Other industries where India has a revealed comparative advantage include petroleum products (334), and hydrocarbons, nes, derivatives (511). In contrast, the Gulf region's RCA is different than India, as their exports is predominantly concentrated to hydrocarbon, petrochemicals and other chemicals (See Table 7).

Table 6: India's RCA Index Values by Industry Classification

\begin{tabular}{|l|c|c|c|c|}
\hline Description & SITC Code (rev.3) & $\begin{array}{c}\text { RCA } \\
(\mathbf{2 0 0 0})\end{array}$ & RCA (2005) & RCA (2008) \\
\hline Food and live animals; Beverages \& tobacco & $\mathbf{0 ~ \& ~ 1 ~}$ & $\mathbf{1 . 9 6}$ & $\mathbf{1 . 6 3}$ \\
\hline - $\quad$ Rice & 042 & 11.02 & 14.28 \\
\hline Crude materials, inedible; Animal, veg. oils, fats, wax & $\mathbf{2 ~ \& ~ 4}$ & $\mathbf{1 . 3 6}$ & $\mathbf{2 . 3 8}$ \\
\hline - $\quad$ Iron ore, concentrates & 281 & 7.54 & 9.65 \\
\hline - $\quad$ Fuels, lubricants, etc & 3 & 0.52 & 0.96 \\
\hline - $\quad$ Petroleum products & 334 & 2.10 & 3.58 \\
\hline - $\quad 4.14$ & 1.35 \\
\hline
\end{tabular}


India-Gulf Trade Relations

\begin{tabular}{|l|c|c|c|c|}
\hline \multicolumn{2}{|c|}{ Chemicals, reltd. pros. nes } & $\mathbf{5}$ & $\mathbf{1 . 2 3}$ & $\mathbf{1 . 1 9}$ \\
\hline Hydrocarbons, nes, derivtvs & 511 & 1.89 & 2.31 \\
\hline Machines, transport equip. & 7 & 0.15 & 0.35 \\
\hline Manufactured goods; Misc. manufactured articles & $\mathbf{6 ~ \& ~ 8}$ & $\mathbf{2 . 3 6}$ & 2.38 \\
\hline \multirow{*}{*}{ Textile yarn } & 651 & 4.32 & 0.52 \\
\hline Textiles articles nes. & 658 & 8.46 & 7.99 \\
\hline
\end{tabular}

Source: Author's calculation based on UNCOMTRADE database.

Table 7: Gulf Region's RCA, 2009

\begin{tabular}{|c|c|c|c|}
\hline Sl. No & Code, Product name & RCA & Share to total GCC exports, $\%$ \\
\hline 1 & 583 Polymerization and copolymerization & 2.46 & 12.1 \\
\hline 2 & 764 Telecommunications equipment & 0.69 & 6.3 \\
\hline 3 & 562 Fertilizers,manufactured & 3.37 & 2.4 \\
\hline 4 & 752 Automatic data processing machines & 0.18 & 0.9 \\
\hline 5 & 274 Sulphur and unroasted iron pyrites & 9.46 & 0.9 \\
\hline 6 & 665 Glassware & 2.05 & 0.8 \\
\hline 7 & 759 Parts of and accessories suitable ... & 0.02 & 0.7 \\
\hline 8 & 691 Structures \& parts of struc.;iron... & 0.38 & 0.7 \\
\hline 9 & 582 Condensation, polycondensation \& ... & 0.63 & 0.7 \\
\hline 10 & 642 Paper and paperboard,cut to size & 0.42 & 0.6 \\
\hline 11 & 661 Lime, cement, and fabricated construct... & 0.22 & 0.5 \\
\hline 12 & 533 Pigments,paints,varnishes\& related & 0.53 & 0.5 \\
\hline 13 & 776 Thermionic,cold\& photo-cathode ... & 1.33 & 0.3 \\
\hline 14 & 692 Metal containers for storage & 0.35 & 0.3 \\
\hline 15 & 273 Stone,sand and gravel & 1.46 & 0.3 \\
\hline 16 & 111 Non alcoholic beverages, n.e.s. & 0.41 & 0.2 \\
\hline 17 & 664 Glass & 0.18 & 0.2 \\
\hline 18 & 423 Fixed vegetable oils,soft,crude & 0.37 & 0.2 \\
\hline 19 & 694 Nails,screws,nuts,boltsetc.of iron & 0.32 & 0.2 \\
\hline 20 & 635 Wood manufactures, n.e.s. & 0.61 & 0.2 \\
\hline
\end{tabular}

Source: Author's calculation based on UNCOMTRADE Database.

\section{Trade Potential Between India And The Gulf Countries}

Free trade between two countries or regions would provide maximum mutual gains from trade for participating countries, if these countries exhibit significant trade potential with each other. Therefore, it seems necessary to examine whether there is considerable trade potential between India and the Gulf region. Maximum one way potential trade between two trading partners can be examined in a simple way by matching the export supply for a given commodity of a country with the import demand for that commodity of a trading partner. By matching the import demand with export supply for a given commodity, an estimate can be gained of the possibility of trade expansion under the most favourable competitive conditions after subtracting existing trade (Rao,1996). Potential trade of a given commodity can therefore be calculated using the following formula:

Trade Potential = [(min, IE, GI) - ET]; whereIE is India's Global (Total) Exports; GI is Gulf's Global (Total) Imports and ET is the existing bilateral exports from India to the Gulf.

This formula in effect creates a 'trade possibility frontier', demonstrating the maximum levels of trade possible within each SITC product category. As in the previous calculations, the import/export and potential trade data used here is for each commodity classification is in millions of USD. Trade data is obtained from the UN Nations Statistical Head Office, New York and from COMTRADE database. Each commodity classification has been aggregated using SITC revision 3 to 1 digit level SITC. The results obtained are then presented in the table 7 below.

Table 8:Potential Trade between India and the Gulf by Commodity Classification, 2009

\begin{tabular}{|c|l|r|}
\hline UN-SITC Code (1 digit) & SITC Code Description & Trade Potential (USD \\
\hline 0 & Food and live animals & 4,389 \\
\hline 1 & Beverages \& tobacco & 147 \\
\hline 2 & Crude materials, inedible & 2,456 \\
\hline 3 & Fuels, lubricants, etc & 2,576 \\
\hline 4 & Animal, vegetable oils, fats, wax, etc. & 105 \\
\hline 5 & Chemical, reltd. pros. nes & 1,569 \\
\hline 6 & Manufactured goods & 4,118 \\
\hline
\end{tabular}




\begin{tabular}{|c|l|l|}
\hline 7 & Machines, transport equip. & 3,279 \\
\hline 8 & Misc. manufactured articles & 1,327 \\
\hline
\end{tabular}

Source: UNCOMTRADE Database, 2011

In summary, there are several potential sectors of India's export interest in the Gulf countries on the basis of static revealed comparative advantage. The RCA analysis also shows that India and the Gulf countries have markedly different export structures and this suggests that India and the Gulf countries do not compete in many areas of merchandise trade except the petroleum and chemical sectors, and thus that there are potential economic benefits to be gained from specialization following bilateral trade liberalization. India possesses a revealed comparative advantage in most of the aggregations of commodities at the 1-digit level. These advantages are relatively weak however, with RCA values of less than 3. In individual industries at a 3-digit level however, a different image appears. India possesses a strong RCA in such industries as rice, and gold / silverware / jewellery. The above quantitative analysis suggests that India's trade with the Gulf region has not achieved optimal outcomes even though huge potential exists for commercial transactions based on comparative advantage/disadvantage and competitive advantage between these two regions. Through this exercise, Indian exporters can easily identify their areas of global revealed comparative advantage (static as well as dynamic) in re-examining the feasibility of exporting such items which are not yet exported to the Gulf region. Table 8 demonstrates significant opportunities for India's trade expansion with the Gulf region. The main categories in which there are potential for India to expand trade are food and live animals (0), crude materials (2), manufacturing (6), as well as the machinery andtransport equipment sectors (7). Food and live animals provides the greatest opportunities, as this is obviously where India's revealed comparative advantage lies.

\section{Conclusions And Policy Recommendations}

The remarkable economic performance of India since 1990s has significant impact on trade with the Gulf region. India's trade with the Gulf region has increased phenomenally over the last decade. However, India's export basket is still concentrated to few traditional items and there is lack of dynamism. Importantly India's trade with the Gulf region is predominantly dominated by exports and imports with the UAE, and Saudi Arabia. There are huge potentials for expanding trade into many sectors and products and also sustaining the burgeoning growth in the future. Therefore it becomes imperative to strive for a holistic strategy solely focused on the Gulf region.

In this regard, it is worthwhile to think about a specialised trade catalyst programme called "Gulf Direct" which should involve government authorities (Ministry of Commerce, Ministry of External Affairs), private sector and trade associations and chambers. For this, certain policy catalysts can be identified such as:

* Expediting the process of FTA negotiation with the GCC region and exploring similar preferential agreements with Iran and Iraq.

* There should be a unified trade representative body/cell in the Gulf region which should carry out market research in coordination with Indian consulates/embassies.

* There should be regular trade promotional activities in the Gulf region in every calendar year.

* Intensive cooperation with the Gulf regional countries at the multilateral forums such as G-20, WTO, IMF, World Bank, etc.

* Given the fact that there is huge scope for trade capacity building in the Gulf region, astute efforts should direct towards more intensive research on sector specific advantages and disadvantages. \&

\section{Appendix Methodology}

This paper used Trade Intensity Index (TII) and Revealed Comparative Advantage (RCA) Index to see trade complementarity and similarity between India and the Gulf countries. The trade intensity index (TII) is used to determine whether the value of trade between two countries is greater or smaller than would be expected on the basis of their importance in world trade. It is defined as the share of one country's exports going to a partner divided by the share of world exports going to the partner. It is calculated as:

$$
\mathbf{T}_{\mathrm{ij}}=\left(\mathbf{x}_{\mathrm{ij}} / \mathbf{X}_{\mathrm{it}}\right) /\left(\mathbf{x}_{\mathrm{wj}} / \mathbf{X}_{\mathrm{wt}}\right)
$$

Where $\mathrm{x}_{\mathrm{ij}}$ and $\mathrm{x}_{\mathrm{wj}}$ are the values of country i's exports and of world exports to country $\mathrm{j}$ and where $\mathrm{X}_{\mathrm{it}}$ and $\mathrm{X}_{\mathrm{w}}$ are country i's total exports and total world exports respectively. An index of more (less) than one indicates a bilateral trade flow that is larger (smaller) than expected, given the partner country's importance in world trade.

Trade Intensity Index is further divided in to Export Intensity Index (EII) and Import Intensity Index (III) for looking the pattern of exports and Imports. Following Kojima (1964) and Drysdale (1969), the index of trade intensity is restated as follows, 
EII between India and the Gulf region $=\left(X_{I G} / X_{I}\right) /\left(\left(M_{A} /\left(M_{w}-M_{I}\right)\right)\right.$

Where, $\mathrm{X}_{\mathrm{IG}}=$ India's Export to the Gulf; $\mathrm{X}_{\mathrm{I}}=$ India's total Export; $\mathrm{M}_{\mathrm{G}}=$ Total Import of the Gulf; $\mathrm{Mw}=$ Total World imports; $\mathrm{M}_{\mathrm{I}}=$ Total Imports of India.

III between India and the Gulf region $=\left(M_{I G} / M_{I}\right) /\left(\left(X_{A} /\left(X_{w}-X_{I}\right)\right)\right.$

$\mathrm{M}_{\mathrm{IG}}=$ Import of India from the Gulf; $\mathrm{M}_{\mathrm{I}}=$ Total Import of India; $\mathrm{X}_{\mathrm{G}}=$ Total Export of the Gulf; $\mathrm{X}_{\mathrm{W}}=$ Total World Export; $\mathrm{X}_{\mathrm{I}}=$ Total Export of India.

Trade Intensity Index is calculated for India and the Gulf countries (excluding Iraq) for the period 1990 to 2008 taking data from IMF Direction of Trade Statistics Database.

Revealed Comparative Advantage Index shows how competitive is a product in countries' export compared to the products share in world trade. A product with high RCA is competitive and can be exported to countries with low RCA. Countries with similar RCA profiles are unlikely to have high bilateral trade intensities unless intra industry trade is involved. RCA measures, if estimated at high levels of product disaggregation, can focus attention on other nontraditional products that might be successfully exported. The RCA index of country ' $i$ ' for product ' $j$ ' is often measured by the product's share in the country's exports in relation to its share in world trade:

$$
\mathbf{R C A}_{\mathrm{ij}}=\left(\mathbf{x}_{\mathrm{ij}} / \mathbf{X}_{\mathrm{it}}\right) /\left(\mathbf{x}_{\mathrm{wj}} / \mathbf{X}_{\mathrm{wt}}\right)
$$

where $x_{i j}$ and $x_{w} j$ are the values of country $i$ 's exports of product $j$ and world exports of product $j$ and where $X_{\mathrm{it}}$ and $\mathrm{X}_{\mathrm{wt}}$ refer to the country's total exports and world total exports. A value of less than unity implies that the country has a revealed comparative disadvantage in the product. Similarly, if the index exceeds unity, the country is said to have a revealed comparative advantage in the product.

In this paper, RCA is calculated for seven Gulf countries (GCC and Iran) across 16 major commodity groups for 18 years to identify specific advantage in trade. The export data used here is for each commodity classification and in millions of USD for the most recent year available for the given trading partner. Each commodity classification has been aggregated using SITC revision 3 to the 1 digit level i.e. $0 \& 1$. The index can be interpreted as follows. An RCA value of less than one indicates that the share of commodity $\mathrm{k}$ in i's exports is less than the corresponding world share of commodity $\mathrm{k}$ in total world exports. This indicates that country i does not have a revealed comparative advantage in the production of commodity $\mathrm{k}$ (World Bank, 2008). However if the value of the index is greater than one, this implies that the country does indeed have a revealed comparative advantage in the production of that product. The data used in these calculations is taken from the International Trade Statistics 2005, 2006, 2007, 2008 and 2009 Yearbooks.

\section{References}

[1]. Ariff, Mohamed and Tan EuChye, (1992), "ASEAN-Pacific Trade Relations ", ASEAN Economic Bulletin, Vol.8, No.3, March.

[2]. Balassa, Bela, (1965), "Trade Liberalization and Revealed Comparative Advantage", The Manchester School of Economic and Social Studies, No. 33: 99-123.

[3]. Balassa, Bela (1977) "'Revealed' Comparative Advantage Revisited: An Analysis of Relative Export Shares of the Industrial Countries, 1953-1971". The Manchester School of Economic \& Social Studies, 45(4): 327-44.

[4]. Batra, Amita and Zeba Khan, (2005), "Revealed Comparative Advantage: An Analysis for India and China". Indian Council for Research on International Economic Relations (ICRIER), Working Paper No. 168, New Delhi.

[5]. Burange, L.G. and Sheetal, J. Chaddha (2008), “India's Revealed Comparative Advantage in Merchandise Trade”. Department of Economics, University of Mumbai, Working Paper UDE 28/06/2008.

[6]. Government of India, (2009), Foreign Trade Policy (FTP), 2009-2010.

[7]. Park, Cyn-Young, RupertoMajuca, and Josef Yap (2010), "The 2008 Financial Crisis and Potential Output in Asia: Impact and Policy Implications", ADB Working Paper Series on Regional Economic Integration.

[8]. Pradhan, Samir Ranjan (2006), India's Export Potential to the GCC Countries", UNESCAP research paper, Bangkok, Thailand

[9]. Pradhan, Samir Ranjan (2008), "India, GCC and the Global Energy Regime: Prospects for Cooperation", Academic Foundation, New Delhi.

[10]. Pradhan, Samir Ranjan (2010), "GCC-India Economic Relations: Prospects and Policy Priorities", paper prepared for the High Level Joint Study Group on GCC-India Relations.

[11]. Rao V.L. and Das R.U. (1996), “Comparative Advantage and Pattern of Trade in Asia- Pacific”, RIS Discussion Paper, September $17-18$.

[12]. UN COMTRADE, (2009) United Nations Commodity Trade Database. (Various Years).

[13]. World Bank (2005), "Trade, Regionalism and Development". Global Economic Prospects, Washington, D. C: World Bank.

[14]. World Bank, (2011), Multipolarity: The New Global Economy, Global Development Horizons 2011, Washington DC.

[15]. World Trade Organisation (WTO) (2010), World Trade Report 2010, Secretariat, Switzerland.

[16]. World Trade Organisation (WTO) (2010) "International Trade Statistics", Geneva. 